\title{
Risk factors framework for information systems projects in public organizations - Insight from Poland
}

\author{
Ewa Ziemba \\ University of Economics in Katowice \\ ul. 1 Maja 50, 40-287 Katowice \\ Poland \\ ewa.ziemba@ue.katowice.pl
}

\author{
Iwona Kolasa \\ University of Economics in Katowice \\ ul. 1 Maja 50, 40-287 Katowice \\ Poland \\ iwona.kolasa@ue.katowice.pl
}

\begin{abstract}
The aim of this study is to answer the question about risk factors for the information system (IS) projects in public organizations in Poland. These factors were identified based on a critical review of literature, practical collaboration, the case study and logical deduction. The paper continues as follows. Firstly, a relationship between risk factors and a project success is explained and risk factors presented in the literature are shown. Secondly, a methodology of examining risk factors for the IS project in public organizations is presented. Thirdly, the risk factors for the IS projects in public organizations in Poland are identified and the framework of risk factors presented in the literature is improved. In this framework the factors are classified into eleven groups, namely (1) top management support; (2) manage processes in organization; (3) involve end users; (4) manage information system development process; (5) make system requirement analysis; (6) plan the project; (7) manage, monitor and evaluate the project; (8) manage project team; (9) manage team experience; (10) manage team communication; and (11) public sector procedures and processes. This paper concludes with a presentation of the study's contribution and limitations, implications for the findings and the stream of future work.
\end{abstract}

\section{INTRODUCTION}

$\mathrm{T}$ HE information systems (IS) projects are always connected to substantial risk. A considerable number of IS projects still use more resources than planned, take longer to complete and provide less quality and functionality than expected [1], [2]. The questions are, what are risk factors for IS projects and how manage risk in IS projects? Among some most common risk factors for IS projects are: unrealistic goals, inaccurate estimation of necessary resources, badly defined requirements, poor presentation of a project status, and unmanaged risk [3], [4]. It has been identified that a poor risk management (RM) of IS projects often leads to failure in IS projects both in public and business organizations [5].

Although some managers claim that they manage risk in their projects, there is evidence that they do not manage it systematically [6]. This shows that public and business organizations should improve not only their ability to identify, but also manage the risk associated with projects [7].

The existing studies mostly examine risk factors for IS projects in business organizations [8]-[10]. There are only few studies concerning risk factors for IS projects in public organizations [11], [12]. This portrays the need for studying risk factors influencing the success of IS projects in public organizations. Therefore, conducting research among Polish public organizations should contribute to greater understanding of risk factors for IS projects and should help fill the gap in the existing body of knowledge.

This article focuses on analyzing risk factors in IS projects in public organizations in Poland. Its aims are to: (1) indicate risk factors for IS projects in public organizations in Poland, and (2) define a risk factor framework for IS projects in public organizations.

The article is structured as follows. Section I is an introduction to the subject. Section II states the theoretical background of risk factors for IS projects. Section III describes a research methodology. Section IV presents the research findings on risk factors for two IS projects in Polish public organizations and the risk factors framework presented in the literature is enhanced. Section V provides the study's contributions and limitations, implications for the findings and the stream of future works.

\section{LITERATURE REVIEW}

\section{A. IS Project Success and Its Risk Factors}

Is there a relationship between risk factors and project success? This question has been considered relevant by people from both academic and practitioners' communities already for a long time, especially in the area of IS, where projects have a long history of failing [13]-[16]. What exactly is defined as risk? Risk is the occurrence of any event that has consequences for, or an impact on the success of an IS project [17]. Many authors define that all projects involve risk of some sort [18]. There is no project without a risk. Risk management (RM), therefore, is one of the main issues of a project. Its positive impact on planning, decision making, avoiding bad events, and giving a proper response to a risky situation is remarkable [19]. RM is both a science and an art for identifying the treats, assessing and controlling them by applying the most effective manner [20].

The success of IS projects is traditionally measured by time, budget and requirements criteria. Many researchers define a project success in terms of compliance with time limits, cost limits and meeting requirements [21]. The significant impact on projects success has RM [22]. It helps to identify and manage risk, and thereby prevent IS projects from getting off the track. RM involves identifying the potential risk, measuring, monitoring and controlling them 
in an organization to meet its strategies and objectives, and leads to decrease the undesired effects in project life cycles.

There is a general consensus that effective planning and implementation of a RM methodology both positively affect the success rate of any project [23]-[26]. There are several methodologies of project RM that represent the course of actions required to manage risk during IS projects [27]. However, the main point is to identify the exact risk factors for IS projects [28]. We found only five papers published after 2010 defining risk factors. Characteristics of the publications are presented in Table I.

Based on the literature findings, there have been identified ten risk groups (RG). Namely, (1) top management support; (2) manage processes in organization; (3) involve end-users; (4) manage information system development process; (5) make business requirement analysis; (6) plan the project; (7) manage, monitor and evaluate the project; (8) manage project team; (9) manage team experience; (10) manage team communication. Each of risk groups is clearly defined by particular risk factors. The compilation of risk factors grouped into risk groups is presented in Table II.

\section{B. Risk Factors for IS Projects in Public Organizations}

In the literature, researchers are conducting studies on identifying risk in public organizations. Patanakul [11] conducted research on large-scale IS projects in the public sector. There were defined the exact risk factors:

- system design and implementation;

- problems in requirement identification;

- project management and governance;

_ problems in managing project risk;

- problems in project monitoring, control and managing changes;

- problems in project governance; and

- contract management.

Aritua, Smith and Bower [12] run research on risk factors in public sector in the UK. The research focused on public organizations' projects in general, not in the context of IS projects. According to them, rejecting the risk of a general nature, specific to certain sectors of the economy, the risk factors can be distinguished as follows:

- linking strategy and projects;
- difficulties in project delivery;

- skills shortage and resources;

- cash flow and funding problems;

- sustainability and environmental legislation;

- challenges of procurement;

- competition for contractors; and

- change in government policy.

Analyzing the above risk factors, it can be noticed, that some of them are the same as defined in the risk groups presented in Table II. However the risk, namely: contract management, challenges of procurement, and change in government policy are not included among the risk defined for business organizations.

\section{Risk Factors Framework for IS Projects}

Risk usually comprises a lot of factors interacting with each other. Researchers have built several frameworks to classify the factors and present relations between them [34], such as the MIT90s framework of Morton [35], the project life-cycle framework of Markus and Tanis [36], the strategic-tactical framework of Holland and Light [37], and the process-control-information (PCI) framework of Bemelmans [38]. The literature presents, that the success of IS projects is dependent on the dynamics and interaction of the organizational and technical factors [39]-[40], [41]. The authors structure and classify the risk factors in the MIT90s framework which covers organizational as well as technical issues. The framework is simple and easily extendable and can, therefore, be used in different settings for multiple purposes [34]. For instance, the framework was applied for supply chain information systems critical success factors [34], [42].

The MIT90s framework contains the following dimensions [35]:

- Project strategy - project goals and how the organization fulfills these goals;

- Structure - process, functions, and structure of the project in organization;

- Individual and roles - the roles, skills, knowledge, social ties and attitudes of people;

- Management process - the management process that steers the implementation project; and

TABLE I.

CHARACTERISTIC OF THE PUBLICATIONS

\begin{tabular}{|l|l|l|}
\hline \multicolumn{1}{|c|}{ Publication } & \multicolumn{1}{|c|}{ Research characteristics } & \multicolumn{1}{c|}{ Research result } \\
\hline S. Liu, L.Wang (2014) & survey, 26 respondents (IS managers) & identified 27 risk factors \\
\hline S. Sundararajan, M. Bhasi, P. K. Vijayaraghavan (2014) & 1 case study & identified 20 risk factors \\
\hline C. Lopez, J.L. Salmeron (2012) & $\begin{array}{l}\text { interview, 12 respondents (IS/IT projects experts); } \\
\text { risk evaluation using IPA method }\end{array}$ & identified 46 risk factors \\
\hline L.Jun, W. Qiuzhen, M. Qingguo (2011) & $\begin{array}{l}\text { survey, 93 respondents; } \\
\text { the influence between factors were measured }\end{array}$ & identified 7 risk factors \\
\hline P.K. Dey, B.T. Clegg, D.J. Bennett (2010) & 1 case study & identified 41 risk factors \\
\hline
\end{tabular}


TABLE II.

RISK FACTORS FOR IS PROJECTS

\begin{tabular}{|c|c|c|c|}
\hline \multirow{4}{*}{\begin{tabular}{|l} 
Group of risk \\
RG1 \\
Top management \\
support
\end{tabular}} & \multicolumn{2}{|c|}{ Risk factor } & \multirow{2}{*}{\begin{tabular}{|l|l|l|l|l|l} 
Source \\
{$[29][30][32]$}
\end{tabular}} \\
\hline & R01 & Lack of top management commitment to the project & \\
\hline & R02 & Top managers make important IT decisions without consulting the others & {$[29][32]$} \\
\hline & R03 & Unrealistic projects outcomes & {$[30][33]$} \\
\hline & R04 & Excessive project size & {$[29][31]$} \\
\hline & R05 & Change in ownership or senior management during the process of development & [30] \\
\hline & R06 & Time too short/too long & {$[29]$} \\
\hline & R07 & Unrealistic schedule & [29] \\
\hline \multirow{5}{*}{\begin{tabular}{|l|} 
RG 2 \\
Manage processes \\
in organization
\end{tabular}} & R08 & Resources shifted away from the project because of changes in organizational priorities & {$[29][30]$} \\
\hline & R09 & Major effect of project implementation on organizational structure & [30] [33] \\
\hline & $R 10$ & $\begin{array}{l}\text { Mismatch between organization culture and required business process changes needed for new } \\
\text { system }\end{array}$ & {$[30]$} \\
\hline & R11 & Changes in organizational priorities & [29] \\
\hline & $\mathrm{R} 12$ & Continuous changes in the organizational environment & [29] \\
\hline \multirow{7}{*}{$\begin{array}{l}\text { RG } 3 \\
\text { Involve end-users }\end{array}$} & R13 & Lack of user participation & {$[29][30][31][32][33]$} \\
\hline & R14 & Users resistant to change & {$[29][30][32]$} \\
\hline & R15 & Target users are unfamiliar with the technology and require additional training & {$[29][30][31]$} \\
\hline & R16 & Users with negative attitudes toward the project & {$[30][32]$} \\
\hline & R17 & User is not committed to the project & {$[29][30]$} \\
\hline & R18 & Users constantly request further changes & [29] \\
\hline & R19 & Conflicts between users departments & [29] \\
\hline \multirow{8}{*}{\begin{tabular}{|l|} 
RG 4 \\
Manage \\
information system \\
development \\
process
\end{tabular}} & R20 & High level of technical complexity & {$[29][30][31][32]$} \\
\hline & R21 & Immature technology & {$[29][30][32][33]$} \\
\hline & $\mathrm{R} 22$ & New technology and use of technology that had not been used in prior projects & {$[29][30][32]$} \\
\hline & R23 & Lack of effective development methodology & {$[30][32][33]$} \\
\hline & R24 & Large number of links to other system required & {$[29][30]$} \\
\hline & R25 & Inadequate system documentation; incomplete or non-existent & {$[29][32][33]$} \\
\hline & R26 & Lack of proper tests & {$[29][32]$} \\
\hline & R27 & Lack of integration between systems & {$[29][32]$} \\
\hline \multirow{6}{*}{$\begin{array}{l}\text { RG 5 } \\
\text { Make system } \\
\text { requirement } \\
\text { analysis }\end{array}$} & R28 & Continually changing scope and system requirements & {$[29][30][32]$} \\
\hline & R29 & Unclear or incomplete system requirements & {$[29][30][33]$} \\
\hline & R30 & System requirements not adequately identified & {$[29][30][32]$} \\
\hline & R31 & Conflicting system requirements & {$[30]$} \\
\hline & R32 & Failure to manage end-user expectations & {$[29]$} \\
\hline & $\mathrm{R} 33$ & Lack of frozen requirements & [29] \\
\hline \multirow{3}{*}{$\begin{array}{l}\text { RG } 6 \\
\text { Plan the project }\end{array}$} & R34 & Poor project planning & {$[29][30][31][32]$} \\
\hline & R35 & Inadequate estimation of required resources & {$[30][32][33]$} \\
\hline & R36 & Critical activities are not identified & [29] \\
\hline \multirow{5}{*}{$\begin{array}{l}\text { RG } 7 \\
\text { Manage, monitor } \\
\text { and evaluate the } \\
\text { project }\end{array}$} & R37 & Project progress not monitored closely enough & {$[29][30][31][32][33]$} \\
\hline & R38 & Lack of an effective project management methodology & {$[29][30][32][33]$} \\
\hline & R39 & Ineffective communication & {$[29][30][32][33]$} \\
\hline & $\mathrm{R} 40$ & Inexperienced project manager & {$[29][30]$} \\
\hline & R41 & Project manager lacks required skills & [29] \\
\hline RG 8 & R42 & Lack of knowledge management & {$[33]$} \\
\hline \multirow{4}{*}{$\begin{array}{l}\text { Manage project } \\
\text { team }\end{array}$} & R43 & Frequent turnover within the development team & {$[29][30][32][33]$} \\
\hline & R44 & Team members are unmotivated & {$[29][32][33]$} \\
\hline & R45 & Inadequate composition of project team & {$[29][32]$} \\
\hline & R46 & Improper definition of roles and responsibilities & {$[29][33]$} \\
\hline RG 9 & R47 & Team members lack of specialized skills required by the project & {$[29][30][31][32]$} \\
\hline \multirow{2}{*}{$\begin{array}{l}\text { Manage team } \\
\text { experience }\end{array}$} & R48 & Inadequately trained development team members & {$[30][32]$} \\
\hline & R49 & Team members are unfamiliar with the technology & [29] \\
\hline RG 10 & R50 & Conflict and no cooperation between the team members & [29] \\
\hline \multirow{2}{*}{$\begin{array}{l}\text { Manage team } \\
\text { communication }\end{array}$} & R51 & Team member are in many localizations & {$[33]$} \\
\hline & $\mathrm{R} 52$ & Inadequate team size & {$[33]$} \\
\hline
\end{tabular}

- Technology - the information system being implemented.

The MIT90s framework indicates that the success of IS projects dependents on the interaction of the organizational and technical system. The framework (Fig. 1) provides opportunities for better understanding of dependency among risk factors. Firstly, risk factors can be grouped into five dimensions of the MIT90s framework which is easy to present from a management perspective. Secondly, the framework of risk factors also provides an understanding of the dynamics and cause-effect relationships of a complex IS projects. The arrows in Fig. 1 indicate that changes in one of the five interacting dimensions are influencing the other. The risk identified in one dimension will cause the higher probability of risk in the other dimension. For example, RG6 Plan the project - the factor R34 Poor project planning, will influence RG8 Manage project team, R45 Inadequate composition of project team. Poorly planned project 


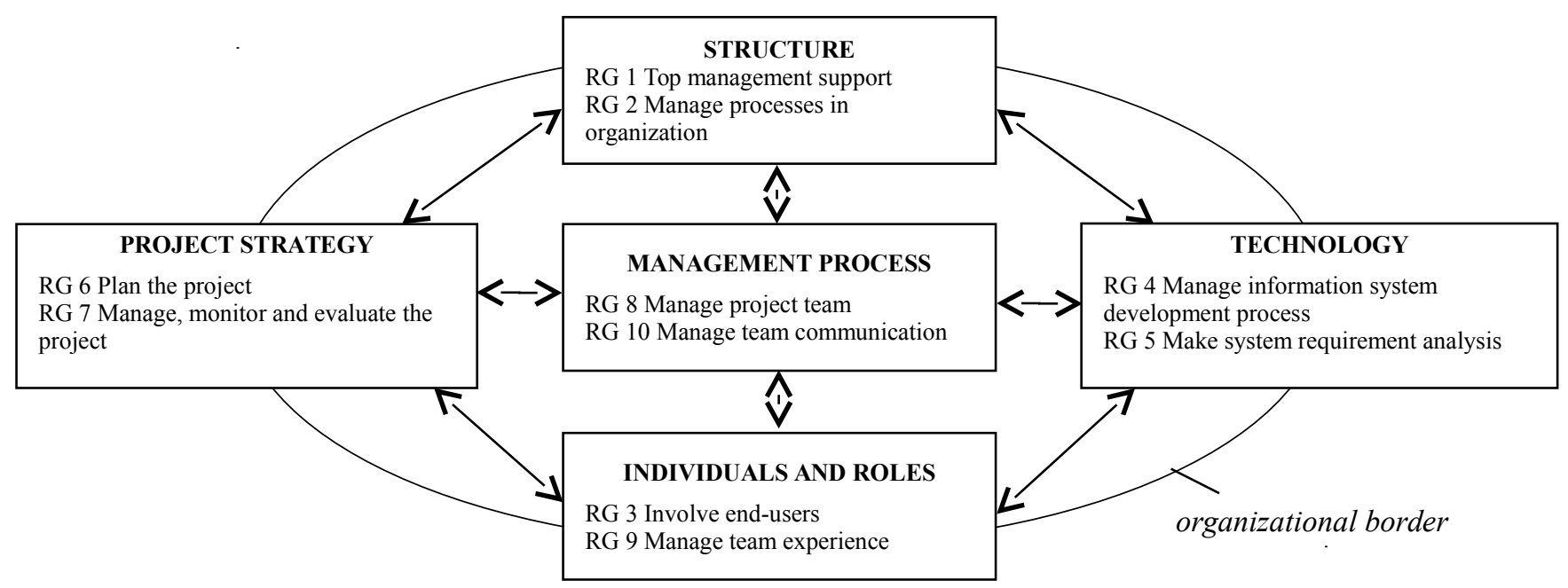

Fig.1. Risk factors framework for IS projects based on Scott Morton [35]

generates risk of underestimation or overestimation of resources.

\section{RESEARCH METHODOLOGY}

The goal of this research was to analyze risk factors for IS projects, described in the literature, in the context of public organizations and identify the most critical ones. The following research questions were posed:

1. What are the risk factors for IS projects?

2. What are the risk factors for IS projects in public organizations?

3. Is there any significant influence between risk factors?

Research methods included a critical review of literature, the case study, practical collaboration and logical deduction. The following steps were taken.

The first step. The empirical evidence was searched aimed at peer-reviewed journal publications from 2010 to 2015 . The process was supported by the use of electronic tools for the search and selection of publications. The search included journals indexed in bibliographic databases, i.e. Ebsco, ProQuest, Science Direct. The search was conducted using a relevant set of keywords and phrases such as "software project" or "information technology project" and "risk management" or "risk factors", and "project success" included in paper abstracts in all possible permutations and combinations (taking into consideration the logical AND, and OR as appropriate). A search was done on the appearance of any combination of these terms, with a result of 933 hits. All hits of 4 pages or less were excluded and narrowed to reviewed academic journals in English. Then, a second selection was made by evaluating the abstracts of the publications selected in the first round of selection. This second round, it was necessary to make sure that the publications included all three topics: software/IT project, project success, and project risk management. The search process resulted in a total of 13 journal publications, published between 2010 and 2015 .
The second step. Risk factors for IS projects were improved on the basis of practical collaboration the authors with IT companies that develop IS systems for business and public organizations.

The third step. After careful evaluation of the literature findings, practical collaboration and logical deduction, risk factors for IS projects were further refined, classified and presented based on MIT90s framework. In the framework, the risk factors were considered in five groups as (1) project strategy, (2) structure, (3) individual and roles, (4) management process, and (5) technology.

The fourth step. Using the case studies approach, the risk factors for IS projects in public organizations in Poland were defined. Moreover, semi-structured interviews with endusers and project team members were conducted as well as shareable documentations related to IS projects management were analyzed during the study. Data was obtained from documents and records such as statement of work, project plan, risk management plan, minutes of meetings, review meetings, reports, project overview presentations and project closure reports. This study was conducted in 2010 and 2013. It concerned IS projects in two Polish public organizations. The IS projects included development and implementation of integrated IS.

The fifth step. The risk factors included in MIT90s framework were evaluated and further developed. The framework was supplemented by additional risk factors defined for RM of IS projects in the public organization.

\section{RESEARCH FINDINGS}

\section{A. Case Studies of IS Projects in Public Organizations}

Public organizations in Poland, due to territorial scope of their operations are divided into public organizations at the state level, embracing the whole Poland, and public organizations at the local levels, district or county. The described case studies of IS projects refer to the state level, where project management took place and the local levels, where IS was implemented. 
Two similar projects, one successful and one not, will be used to present the application of risk factors in IS projects [43]. Information about a project was gathered by participation in those projects and conducting series of semistructured interviews. Data was obtained from documents and records such as statement of work, project plan, risk management plan, minutes of meetings, review meetings, reports, project overview presentations and project closure reports.

Table III shows that those two projects were similar in terms of scope and size. As a result, the outcomes of the projects were different. Project A ended only as a partial success. Finally, IS was implemented but it was not fully used by the end-users after 12 months. The completion of Project A was also significantly delayed. Project B was fully successful. IS was implemented and it is fully used by its end-users.

Project A was carried by a public organization at the state level. The aim of the project was to improve and automate government processes and to implement an integrated information system, i.e. an ERP system in sixteen public organizations at the local levels. The ERP system used to this point of time was out of date. The results of change were to centralize management of the organizational structure of all sixteen public organizations and automation of supporting government processes for finance and accounting, human resources management, payroll management, inventory management, and fixed assets management. The expected benefits of the project were to eliminate unnecessary documentation, systemize document circulation, ensure a smooth flow of information, and make information accessible (which is relevant, timely to appropriate users and in an appropriate form). A specifically set up project team of the central public organization was responsible for the implementation of the ERP system. The project team was composed of people from the departments of the central public organization, such as: accounting, human resources, payroll, fixed assets, and inventory management, and from the IT department. Moreover, the project team was supported by the members of IT company, especially business analysts, systems analysts, and project team leaders.

Project A was managed using PRINCE2 methodology, however only few documents were created. There was created a risk procedure, however the risk was never escalated to steering committee. The risk registry was fulfilled at the beginning of the project, but was not updated during the project. The project team was not properly instructed about necessity of risk reporting. The basic risk management approach was missing. The risk was not properly managed. Often the risk was not identified but happened as an issue.

Project B was also carried out by a public organization. The aim of the project was to implement IS for supporting processes of service provision for citizens. As a result of the project the following types of IS were implemented: integration platform, business intelligence, enterprise portal, web based information portal and mobile terminal software. The project was undertaken as a consequence of the diagnosed problems arising from the lack of IT system integration. The lack of integration made it impossible to have quick access to information indispensable for effective functioning and monitoring of operations of public organizations and caused an ineffective flow of information between the public organizations and the cooperating institutions. The lack of system cooperation compounded the difficulties in monitoring funds allocation and expenditure, and the difficulties in monitoring the use of funds by individual public organizations.

Project B was managed using PRINCE2 methodology, where all necessary documents essential for effective project management were created. The project team was formally established. Particular people were permanently assigned to particular parts of the project. Their scope of responsibilities was explicitly defined. The project team consisted of an IT specialist group and a government group made up of specialists who were the main users of the system. Risk management was conducted concurrent with the project implementation. The end-users participated in a series of conferences, where a clearly defined project goal and

TABLE III.

PROJECT A AND PROJECT B - COMPARISON OF BASIC VARIABLES

\begin{tabular}{|l|l|l|}
\hline \multicolumn{1}{|c|}{ Features } & \multicolumn{1}{|c|}{ Project A } & \multicolumn{1}{c|}{ Project B } \\
\hline Project type & Information system & Information system \\
\hline Sector & Public organizations & Public organizations \\
\hline Initial schedule & 12 months & 18 months \\
\hline Budget & Realistic & Realistic \\
\hline Success criteria & $\begin{array}{l}\text { On time, within budget, successful installation of ERP } \\
\text { system }\end{array}$ & $\begin{array}{l}\text { On time, within budget, successful installation of } \\
\text { web-based information system }\end{array}$ \\
\hline IS software & Custom made & Custom made \\
\hline Customers & Public organization employees & $\begin{array}{l}\text { General public, } \\
\text { Public organizations employees }\end{array}$ \\
\hline No of end users & 400 & 35 000 \\
\hline $\begin{array}{l}\text { Project management } \\
\text { methodology }\end{array}$ & $\begin{array}{l}\text { PRINCE2 } \\
\text { (full documentation needed were created) }\end{array}$ \\
\hline Risk management & No (no risk registry provided) & Yes (risk registry provided) \\
\hline Project result after 12 months & Software was made but not fully used after 12 months & Software was made and fully used after 12 months \\
\hline
\end{tabular}


successively accomplished tasks were presented. Moreover, they actively participated in analysis meetings where they defined the system requirements. The project had a coherently worked-out schedule that also included a business team meeting schedule. The business team was kept informed about the project progress and participated in the final IS testing.

\section{B. Risk Management of IS Projects in Public Organizations}

In project $\mathrm{A}$, the risk was not identified and managed. Whereas, RM was applied to project B in a methodologically correct manner.

Based on the examination of the case studies, the authors can draw the same observations (Table IV). Obviously, it can be stated that in case of project A, 27 risk factors did not occur, although 25 risk factors occurred and they were not managed. The lack of RM could have contributed to the failure of the IS project. Finally, IS was created and implemented with a significant delay. In case of project B, 38 risk factors did not occur, and 14 risk factors occurred and they were managed. Project B was completed on the schedule. It can be assumed that RM played a significant role in the IS project success.

However, there were several other risk factors which were not included in the risk factors framework for business organizations (Fig. 1). They were:

- changing government processes during project implementation;

- changing and inconsistent legal regulatory framework;

- challenges of procurement procedure;

- financial capability of project contractor; and

- managing contract.

Changing government processes during project implementation. Changes in government processes during the project always generate the need to change the IS requirements. The changes of IS requirements are one of the most frequent reasons of IS project failures. The change of requirements influences the scope of the project and its functionalities and can extend the project duration.

Changing and inconsistent legal regulatory framework. Changes to the rule of law which take place during the project can affect and often affect IS requirements. As it was mentioned above, the change to the requirements influence the scope of the project and its functionality and can extend the project duration. Unfortunately, the changes to Polish legal system are frequent. It is partially connected with the fact that recently the Polish economy has gone through the transition from a central planned economy to a market economy and it had to adjust and is still adjusting the legal system to the market economy.

Challenges of procurement procedure. There are several factors which must be met in a procurement procedure. One criterion of offer evaluation must be a price. Other criteria may be freely chosen depending on the object of the contract, e.g. quality, technical merit, functionality, usability. Typically, a tender is chosen using the price criterion. In Poland, the cheapest offer is often chosen. As a result the ratio of price to quality is not always maintained.

Financial capability of project contractor. The payment for the contractor for the works done within the IS project framework takes place after the final IS technical acceptance. In practice it may take from few to several months. During this time the contractor has to cover the running costs from own resources. This creates the risk of losing financial liquidity if the contractor does not have appropriate financial backing.

Managing contract. An effectively managed contract can impact on a timely completion of IS project. However, it is extremely difficult to predict all conditions that may occur during the contract realization process. There is a need for long term planning and considering, e.g. identifying all current and future systems that must be integrated. There is a high risk that some minor requirements might be omitted in the contract. The contract cannot be significantly changed

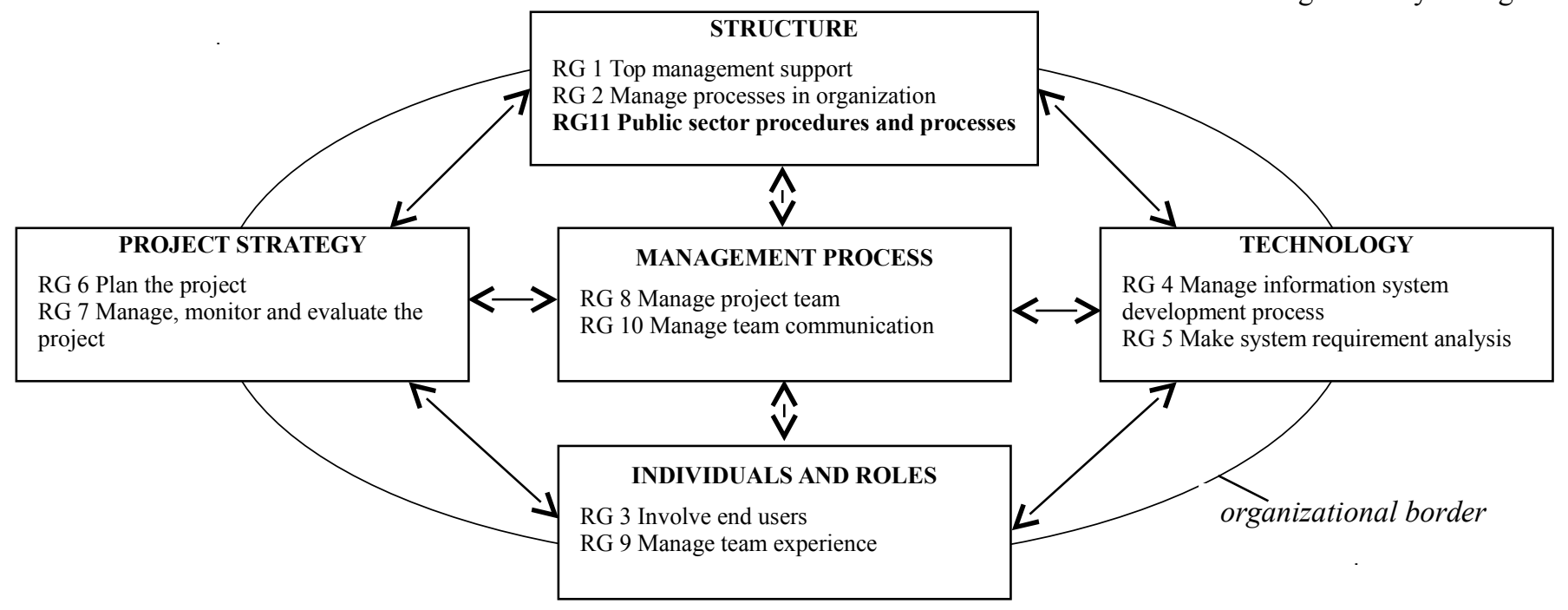

Fig. 2. Risk factors framework for IS projects in public organizations 
during the project, as it is one of the procurement procedures.

\section{Risk Factors Framework for IS Projects in Public Organizations}

The above identified risk factors for IS projects in public organizations are creating the new risk factors group: public sector procedures and processes. This group is included in the risk factors framework proposed by Morton and presented in Fig. 1. The new group of risk factors was classified into the framework dimension named Structure. The factors are the part of this dimension, because they are related to processes and functions of IS projects in public organizations. Furthermore, they influence project strategy, management process and technology. The enhanced risk factors framework for IS projects in public organizations is presented in Fig. 2.

As mentioned above, public sector procedures and processes have an impact on project strategy. Especially, they affect project planning which has to account for such identified risk factors as a procurement procedure, changing government processes and financial capability of project contractor. Public sector procedures and processes also influence managing, monitoring and evaluating IS project as they are more complex and have to account for additional identified risk factors. Public sector procedures and processes have an impact on management process. Managing contracts, in particular, requires from managers specialist experience and the knowledge of the rule of law.

Public sector procedures and processes also influence technology. Changes to the requirements caused by changing government processes or a legal regulatory framework must be reflected in IS projects, especially in IS functionality. Moreover, these changes often result in delays in the IS project implementation. The potential changes to the IS project lead time are limited by the procurement procedure.

In conclusion, public organizations must take into account more risk factors in the risk management of IS projects than business organizations. Fig. 2 presents the framework of risk factors for IS projects in public organizations.

\section{CONCLUSION}

Identifying and understanding risk factors is crucial for the success of IS projects in public organizations. The paper enhances the framework of risk factors identified in the literature and proposes a comprehensive risk factors framework for IS projects in public organizations.

This study contributes to the research on risk factors for IS projects in two ways. Firstly, the risk factors for IS projects in business organization are analyzed and presented. Secondly, the unique risk factors for IS projects in public organizations are identified based on the case studies approach. In summary, there are eleven groups of risk factors for IS projects in public organizations, namely (1) top management support; (2) manage processes in organization; (3) involve end users; (4) manage information system development process; (5) make system requirement analysis; (6) plan the project; (7) manage, monitor and evaluate the project; (8) manage project team; (9) manage team experience; (10) manage team communication (11) public sector procedures and processes. Moreover, the proposed risk factors framework for public organization is based on MIT90s framework. The framework indicates that risk factors are not standing alone, but they influence each other.

In this research, public organizations could find knowledge related to the risk factors impacting on successful IS projects. Especially, this research can be useful for the Central and Eastern European countries. This is because the countries are similar. Their similarity concerns their analogous geopolitical situation, their joint history, traditions, culture, and values. In addition, the similarity reflects in building democratic state structures and a freemarket economy, participating in the European integration process, the levels of information systems implementation in public organizations. Moreover, they have to resolve the same problems and overcome the same political, economic, social, technological obstacles in their transition from traditional public organizations to organizations based on information systems.

As with many other studies, this study has its limitations. The main is that, it is only based on two case studies in Poland. Caution should be taken when generalizing our findings. The issues of risk factors for IS projects in public organizations, therefore, should be explored in greater depth. There is a need to examine other case studies, and verify and enhance the risk factors framework. This will be considered as a future work.

\section{ACKNOWLEDGMENT}

This research has been supported by a grant entitled "Transformation of business and public administration by information technology and information systems" from the University of Economics in Katowice, Poland, 2014-2016.

\section{REFERENCES}

[1] M.O. Barros, C.M.L. Werner, and G.H. Travassos, "Supporting risks in software project management," Journal of Systems and Software, vol. 70(1-2), pp. 21-35, 2004.

[2] R.R. Nelson, "IT project management: Infamous failure, classic mistakes, and best practices," MIS Quarterly Executive, vol. 6(2), pp. 67-78, 2007.

[3] R.N. Charette, "Why software fails," IEEE Spectrum, vol 42(9), pp. 42-49, 2005.

[4] K. Bock and S. Trück, "Assessing uncertainty and risk in public sector investment projects," Technology and Investment, vol. 2, pp. 105-123, 2011.

[5] L. Zhou, A. Vasconcelos, and M. Nunes, "Supporting decision making in risk management through an evidence-based information systems project risk checklist," Information Management \& Computer Security, vol. 16, no. 2, pp. 166-186, 2008.

[6] P.K. Dey, J. Kinch, and S.O. Ogunlana, "Managing risk in software development projects: A case study," Industrial Management end Data Systems, vol. 107(2), pp. 284-303, 2007.

[7] J.J. Jiang, G. Klein, and R. Discenza, "Information system success as impacted by risks and development strategies," IEEE. Transactions on Engineering Management, vol. 48 (1), pp. 46 -55, 2001.

[8] A. Jani, "Escalation of commitment in troubled IT projects: Influence of project risk factors and self-efficacy on the perception of risk and 
TABLE IV

RISK FACTORS EVALUATION FOR PROJECT A AND PROJECT B

\begin{tabular}{|c|c|c|c|}
\hline & Risk factor & Project A & Project B \\
\hline $\mathrm{R} 01$ & Lack of top management commitment to the project & occurred, not identified, not managed & not occurred \\
\hline R02 & $\begin{array}{l}\text { Resources shifted away from the project because of changes in } \\
\text { organizational priorities }\end{array}$ & not occurred & not occurred \\
\hline R03 & Major effect of project implementation on organizational structure & not occurred & not occurred \\
\hline $\mathrm{R} 04$ & $\begin{array}{l}\text { Top managers make important IT decisions without consulting the } \\
\text { others }\end{array}$ & occurred, not identified, not managed & not occurred \\
\hline $\mathrm{R} 05$ & Unrealistic projects outcomes & not occurred & not occurred \\
\hline R06 & $\begin{array}{l}\text { Change in ownership or senior management during the process of } \\
\text { development }\end{array}$ & not occurred & not occurred \\
\hline R07 & Excessive project size & not occurred & not occurred \\
\hline $\mathrm{R} 08$ & $\begin{array}{l}\text { Mismatch between organization culture and required business process } \\
\text { changes needed for new system }\end{array}$ & not occurred & not occurred \\
\hline R09 & Changes in organizational priorities & not occurred & not occurred \\
\hline R10 & Continuous changes in the organizational environment & not occurred & not occurred \\
\hline R11 & Time too short/too long & occurred, not identified, not managed & occurred, identified, managed \\
\hline $\mathrm{R} 12$ & Unrealistic schedule & occurred, identified, not managed & occurred, identified, managed \\
\hline R13 & Lack of user participation & occurred, identified, not managed & not occurred \\
\hline R14 & Users resistant to change & occurred, identified, not managed & occurred, identified, managed \\
\hline R15 & $\begin{array}{l}\text { Target users are unfamiliar with the technology and require additional } \\
\text { training }\end{array}$ & occurred, identified, not managed & occurred, identified, managed \\
\hline R16 & Users with negative attitudes toward the project & occurred, not identified, not managed & not occurred \\
\hline $\mathrm{R} 17$ & User is not committed to the project & occurred, identified, not managed & not occurred \\
\hline R18 & Users constantly request further changes & occurred, identified, not managed & occurred, identified, managed \\
\hline R19 & Conflicts between users departments & occurred, identified, not managed & occurred, identified, managed \\
\hline $\mathrm{R} 20$ & High level of technical complexity & not occurred & occurred, identified, managed \\
\hline R21 & Immature technology & not occurred & not occurred \\
\hline $\mathrm{R} 22$ & $\begin{array}{l}\text { New technology and use of technology that had not been used in prior } \\
\text { projects }\end{array}$ & not occurred & not occurred \\
\hline R23 & Lack of effective development methodology & not occurred & not occurred \\
\hline $\mathrm{R} 24$ & Large number of links to other system required & occurred, identified, managed & occurred, identified, managed \\
\hline $\mathrm{R} 25$ & Inadequate system documentation; incomplete or non-existent. & not occurred & not occurred \\
\hline $\mathrm{R} 26$ & Lack of proper tests & not occurred & not occurred \\
\hline $\mathrm{R} 27$ & Lack of integration between systems & occurred, identified, managed & occurred, identified, managed \\
\hline $\mathrm{R} 28$ & Continually changing scope and system requirements & occurred, identified, not managed & occurred, identified, not managed \\
\hline $\mathrm{R} 29$ & Unclear or incomplete system requirements & occurred, identified, not managed & not occurred \\
\hline R30 & System requirements not adequately identified & occurred, identified, not managed & not occurred \\
\hline R31 & Conflicting system requirements & not occurred & not occurred \\
\hline R32 & Failure to manage end-user expectations & occurred, identified, managed & occurred, identified, managed \\
\hline $\mathrm{R} 33$ & Lack of frozen requirements & not occurred & not occurred \\
\hline R34 & Poor project planning & occurred, not identified, not managed & not occurred \\
\hline $\mathrm{R} 35$ & Project progress not monitored closely enough & occurred, not identified, not managed & not occurred \\
\hline R36 & Lack of an effective project management methodology & occurred, not identified, not managed & not occurred \\
\hline $\mathrm{R} 37$ & Ineffective communication & not occurred & occurred, identified, managed \\
\hline R38 & Inadequate estimation of required resources & not occurred & not occurred \\
\hline R39 & Inexperienced project manager & not occurred & not occurred \\
\hline R40 & Project manager lacks required skills & not occurred & not occurred \\
\hline R41 & Critical activities are not identified & occurred, not identified, not managed & not occurred \\
\hline $\mathrm{R} 42$ & Lack of knowledge management & not occurred & not occurred \\
\hline R43 & Frequent turnover within the development team & not occurred & not occurred \\
\hline $\mathrm{R} 44$ & Team members lack of specialized skills required by the project & occurred, identified, not managed & occurred, identified, managed \\
\hline R45 & Inadequately trained development team members & not occurred & not occurred \\
\hline R46 & Team members are unmotivated & occurred, identified, not managed & not occurred \\
\hline R47 & Inadequate composition of project team & not occurred & not occurred \\
\hline $\mathrm{R} 48$ & Team members are unfamiliar with the technology & occurred, not identified, not managed & not occurred \\
\hline R49 & Conflict and no cooperation between the team members & occurred, not identified, not managed & occurred, identified, managed \\
\hline $\mathrm{R} 50$ & Improper definition of roles and responsibilities & not occurred & not occurred \\
\hline $\mathrm{R} 51$ & Team member are in many localizations & not occurred & not occurred \\
\hline $\mathrm{R} 52$ & Inadequate team size & not occurred & not occurred \\
\hline
\end{tabular}

the commitment to a failing project," International Journal of Project Management, vol. 29, pp. 934-945, 2011

[9] M. Keil, L. Wallace, D. Turk, G. Dixon-Randall, and U. Nulden, "An investigation of risk perception and risk propensity on the decision to continue a software development project" The Journal of Systems and Software, vol. 53(2), pp. 145-157, 2000.
[10] D. Tesch, T.J. Kloppenborg, and M.N. Frolick, "IT project risk factors: The project management professional's perspective," Journal of Computer Information Systems, vol. 47(4), pp. 61-69, 2007.

[11] P. Patanakul, "Managing large-scale IS/IT projects in the public sector: Problems and causes leading to poor performance," Journal of High Technology Management Research, vol. 25, pp. 21-35, 2007. 
[12] B. Aritua, N.J. Smith, and D. Bower, "What risks are common to or amplified in programmes: Evidence from UK public sector infrastructure schemes," International Journal of Project Management, vol. 29, pp. 303-312, 2011.

[13] B. Whittaker, "What went wrong? Unsuccessful information technology projects," Information Management \& Computer Security, vol. 7(1), pp. 23-30, 1999.

[14] D. Baccarini, G. Salm, and P.E.D. Love, "Management of risks in information technology projects," Industrial Management \& Data Systems, vol. 104 iss: 4, pp. 286-295, 2004

[15] J. Wateridge, "IT projects: A basis for success," International Journal of Project Management, vol. 13, issue 3, pp. 169-172, June 1995.

[16] M. Yildiz, "E-government research: Reviewing the literature, limitations, and ways forward," Government Information Quarterly, vol. 24, issue 3, pp. 646-665, July 2007.

[17] R. Kliem and I. Ludin, "Reducing project risk," Gower Publishing Limited, Aldershot, 2000

[18] J. Cadle and D. Yeate, Project Management for Information Systems, Financial Times/Prentice-Hall, Harlow, 2001.

[19] O. Zwikael, R.D. Pathak, G. Singh, and S. Ahmed, "The moderating effect of risk on the relationship between planning and success," International Journal of Project Management, vol. 32, pp. 435-441, 2014.

[20] R. McGaughey Jr, Ch.A. Snyder., and H.H. Carr, "Implementing information technology for competitive advantage," Risk Management issues, pp. 273-280, 1994.

[21] K. Jugdev, D. Perkins, J. Fortune, D. White, and D. Walker, “An exploratory study of project success with tools, software and methods," International Journal of Managing Projects in Business, vol. 6, no. 3, pp. 534-551, 2013.

[22] R. Rabechini J. and M.M. de Carvalho, "Understanding the impact of project risk management on project performance: An empirical study", Journal of Technology Management \& Innovation, vol. 8, pp. 64-78, 2013.

[23] T. Raz and E. Michael, "Use and benefit of tools for project risk management," International Journal of Project Management, vol. 19(1), pp. 9-17, 2001.

[24] A. Nalewaik, "Risk management for pharmaceutical project schedules," AACE International Transactions. Risk, vol. 07, pp. 71$75,2005$.

[25] T.K. Das and B.S. Teng, "Managing risks in strategic alliances," The Academy of Management Executive, vol. 13(4), pp. 50-62, 1999.

[26] P. Cook, "Formalized risk management: vital tool for project- and business-success," Cost Engineering, vol. 47(8), pp. 12-13, 2005.

[27] V. Holzmann and I. Spiegler, "Developing risk breakdown structure for information technology organizations," International Journal of Project Management, vol. 29, pp. 537-546, 2011.

[28] M. Keil, P. Cule, K. Lyytinen, and R. Schmidt, "A framework for identifying software project risks," Communication of the ACM, vol. 41 , no. 11 , pp. $76-83,1998$.
[29] C. López, J. and L. Salmeron, "Risks response strategies for supporting practitioners decision-making in software projects," Procedia Technology, vol. 5, pp. 437-444, 2012.

[30] S. Liu and L. Wang, "Understanding the impact of risks on performance in internal and outsourced information technology projects: The role of strategic importance", International Journal of Project Management, vol. 32, pp. 1494-1510, 2014.

[31] L. Jun, W. Qiuzhen, and M. Qingguo, "The effects of project uncertainty and risk management on IS development project performance: A vendor perspective," International Journal of Project Management, vol. 29, pp. 923-933, 2011.

[32] P.K. Dey, B.T. Clegg, and D.J. Bennett, "Managing enterprise resource planning projects," Business Process Management Journal, vol. 16, no. 2, pp. 282-296, 2010.

[33] S. Sundararajan, M. Bhasi, and P.K. Vijayaraghavan, "Case study on risk management practice in large offshore-outsourced Agile software projects," IET Software, doi: 10.1049/iet-sen.2013.0190.

[34] J.M. Denolf, J.H. Trienekens, P.M. Wognum, J.G. A. J. Vander Vorst, and S.W.F. (Onno), Omta, "Towards a framework of critical success factors for implementing supply chain information systems," Computers in Industry, vol. 68, pp. 16-26, 2015.

[35] M.S. Scott Morton, The corporation of the 1990s: Information technology and organizational transformation, Oxford University Press, New York, 1991.

[36] M.L. Markus and C. Tanis, The enterprise systems experience-from adoption to success, in: R.W. Zmud (Ed.), Framing the domains of IT research: Glimpsing the future through the past, Pinnaflex Educational Resources, Inc., Cincinnatti, OH, pp. 173-207, 2000.

[37] C.P. Holland and B. Light, "A critical success factors model for ERP implementation," IEEE Software, vol. 16(3), pp. 30-36, 1999.

[38] T. Bemelmans, Administrative Information Systems and Automation, Kluwer Bedrijfswetenschappen, Deventer, The Netherlands, 1998.

[39] W.J. Orlikowski, "The duality of technology: rethinking the concept of technology in organizations," Organization Science, vol. 3(3) pp. 398427, 1992.

[40] T. H. Davenport, Mission critical: Realizing the promise of enterprise systems, Harvard Business Press, Boston, MA, 2000.

[41] N.F. Doherty and M. King, "From technical to socio-technical change: tackling the human and organisational aspects of systems development projects," European Journal of Information Systems, vol. 14(1) pp. 1$5,2005$.

[42] M.J. Verdecho, J.J. Alfaro-Saiz, R. Rodriguez-Rodriguez, and A. Ortiz-Bas, "A multi-criteria approach for managing inter-enterprise collaborative relationships," Omega, vol. 40 (3), pp. 249-263, 2012.

[43] E. Ziemba and I. Obłak, "Change management in information systems projects for public organizations in Poland," Interdisciplinary Journal of Information, Knowledge, and Management, vol. 10, pp. 47-62, 2015 . 